\title{
Enhancing Critical Thinking Skills through Political Cartoons: A Pedagogical Implementation'
}

\author{
Mejora de las habilidades de pensamiento crítico a \\ través de las caricaturas políticas: una implementación \\ pedagógica.
}

\author{
Maria Teresa Esteban Nuñez, Adriana Marquez Medina \\ and Jhon Everth Ortiz Cubides ${ }^{2 *}$ \\ Universidad Pedagógica y Tecnológica de Colombia, Colombia
}

\begin{abstract}
This article reports a pedagogical implementation carried out with preintermediate English students, in an English teacher preparation program at a public university in Colombia. This pedagogical implementation aimed to provide this population with a space to enhance their critical thinking skills through the implementation of a variety of task-based workshops where they were asked to observe, analyze, reflect and discuss about some political cartoons. The data to answer the research question was collected using class video-recordings, students' artifacts and a focus group. As a result of the pedagogical implementation, it was possible to identify how these students became aware of some social and political issues affecting them and their close context, and the importance of stating a position in front of them. Furthermore, students suggested that the workshops developed had shown them a possible pedagogical path they could follow in their future as language teachers.
\end{abstract}

Key Words: Political Cartoons, Critical Thinking Skills, Task-Based Approach.

\section{Resumen}

Este artículo reporta una intervención pedagógica desarrollada con estudiantes de inglés pre-intermedio, de un programa de formación de maestros en una

\footnotetext{
1 Received: January 31st 2018/ Accepted: June 5th 2018

2 aireste@yahoo.es; adri.marquez1995@hotmail.com; Jhon.e-123@hotmail.com
} 
universidad pública en Colombia. Esta intervención pedagógica buscaba proveer a esta población con un espacio para mejorar sus habilidades de pensamiento crítico a través de la implementación de una variedad de talleres basados en tareas donde se le pidió observar, analizar, reflexionar y discutir sobre algunas caricaturas políticas que fueron abordadas en sus clases de inglés. Para recolectar datos para analizar la pregunta de investigación se usaron grabaciones de video de las clases, artefactos de los estudiantes y un grupo focal. Como resultado de la implementación pedagógica, fue posible identificar cómo estos estudiantes tomaron conciencia de algunos problemas sociales y políticos que afectan a ellos y su contexto cercano y la importancia de establecer una posición frente a ellos. Además, los estudiantes sugirieron que los talleres desarrollados les habían mostrado un posible camino pedagógico que podrían seguir en su futuro como profesores de idiomas.

Palabras Clave: Caricaturas Políticas, Habilidades de Pensamiento Crítico, Enfoque Basado en Tareas.

\section{Resumo}

Este artigo apresenta uma intervenção pedagógica desenhada para prover a estudantes de Inglês pré-intermédio, de um programa de formação de mestres em uma universidade pública na Colômbia, um espaço para melhorar o seu pensamento crítico através da implementação de oficinas baseadas em tarefas onde observavam, analisavam, refletiam e discutiam sobre caricaturas políticas que foram abordadas nas suas aulas de inglês. Para coletar dados para analisar a pergunta de pesquisa se usaram gravações de vídeo, artefatos dos estudantes e discussões de grupo. Como resultado da implementação deste estudo, os estudantes reconheceram o papel ativo como cidadãos que devem assumir responsabilidades nas suas comunidades, eles também argumentaram que as oficinas foram úteis para melhorar o seu pensamento crítico e ao longo de cada atividade foi possível evidenciar como seus argumentos foram fortalecendo-se.

Palavras Chave: Caricaturas Políticas, Pensamento Crítico, Enfoque Baseado em Tarefas. 


\section{Introduction}

$\mathrm{E}$ ducation should contribute in the construction of autonomous, active and critical beings, capable of analyzing, reasoning, reflecting, making decisions, and solving problems not only in their lives but also in their societies. As language teachers, we considered that one of the main objectives of English foreign language education is to open spaces where students can move along the different cognitive processes previously mentioned.

Our research study focused on implementing five task-based workshops that were designed based on social and political issues portrayed in political cartoons. Our main intention was to provide participants with a space for them to reflect, discuss and state positions in front of the issues approached in those new texts: political cartoons. This study was developed with pre-intermediate English-students.

Currently information is presented through different types of texts; one of these texts is political cartoons which commonly are designed to show particular realities in a satirical manner. In the Colombian context, cartoons, but specifically political cartoons have been used as texts to portray social and political issues affecting the Colombian society.

The cartoons selected for this research reflected different problematic situations like corruption, gender inequality, obsession to social networks, migration, and global warming which are common in Colombia and therefore in the contexts where these participants live in. These cartoons could be placed in what El Refaie \& Horschelmann (2010) identify as political cartoons. For these authors political cartoons describe reality of social and political issues from a critical point of view.

Dougherty (2002) states that "political cartoons are an excellent classroom tool to build students' critical thinking skills, to generate lively classroom discussions, and to get students excited about politics" (p. 258). These were the main reasons why political cartoons were proposed for this group in particular. Our intention was to identify and analyze whether or not the implementation of some political cartoons developed or fostered pre-intermediate English students' critical thinking skills.

As researchers, we strongly believe that beyond teaching students how to read the word, it is necessary to guide them to read the world; therefore, it is necessary to enhance students' critical thinking skills. With this purpose in mind five task-based workshops were designed to 
provide these students with spaces where they analyzed, discussed and reflected about different political cartoons.

The next section of this paper presents some national and international studies conducted by other teacher- researchers who have approached cartoons and critical thinking skills to foster their teaching and learning processes in higher education. The objective of this section is to establish the relevance of previous research to our general field of study: critical thinking.

\section{Literature Review}

Arango, Gomez \& Gomez (2009) conducted a research study where cartoons were considered as a tool for higher education teaching. Its objective was to establish conditions and characteristics cartoons should have as tool for teaching. They concluded that cartoons has a didactic potential, which has been underused for teaching and that higher education institutions should encourage its use and do research for validating its potential.

El Refaie \& Horschelmann (2010) studied young people's responses to a newspaper cartoon as a way of exploring the concept of multimodal literacy. The study aimed to elicit the geopolitical views of 16-19-year-olds in a multiethnic British city by using cartoons as a way of encouraging them to talk about their thoughts and feelings towards recent political events. They found that contrary to popular perceptions, political cartoons are complex and could have more than one meaning, and therefore require a particular form of literacy.

Ibarra \& Ballester (2015) explored the relationship between comic, interculturality and literary education and they provided an illustrative picture of the emergence of multiculturalism in contemporary cartoon. They observed the use of comics as a top pedagogical strategy by different institutions and highlighted the interest of the new generations in this type of text.

These three previous studies provided us with different information related to theoretical constructs to support our study. Their findings in terms of cartoons as didactic resources and the activities developed by these researchers guided the design of the workshops we applied in our pedagogical implementation.

A different study conducted by Arias (2014) focused on showing how music can help students to enhance their critical thinking processes through the implementation of implicit content of songs in the EFL 
classroom. This last study remarks the importance of applying-problem based activities in order for students to have a critical vision of the issues that affect the current world. This study motivated us to explore and create a different environment for our classes bearing in mind our students' previous knowledge and their experiences.

Carvajal, Poveda and Rojas (2012) conducted an action research study focused on critical thinking skills development in an NGO with displaced children of elementary English language level. These researchers designed a didactic unit with the objective of contributing in the development of some critical thinking skills in the population under study. Their findings evidenced the progress these kids had in two dimensions: cognitive and affective. They also identified that questioning was one of the most effective strategies to develop critical thinking skills.

Based on the results presented in the study conducted by Carvajal et al. (2012), we decided to include questions in the five workshops as a fundamental component for each of the workshops developed during the data collection process. These questions were addressed at different stages during the task-based cycle.

\section{Theoretical Framework}

This study is held on a frame of constructs that guided and supported our path to explore and find answers to our inquiry. We begin by defining critical thinking, then critical thinking skills; finally, we conceptualize the concept of cartoons and describe the core of our study: political cartoons.

\section{Critical thinking}

Critical thinking is a complex term and it has been defined in several ways. Scriven \& Paul (2007) have defined it as "the intellectually disciplined process of actively and skillfully conceptualizing, applying, analyzing, synthesizing, and/or evaluating information gathered from, or generated by, observation, experience, reflection, reasoning, or communication, as a guide to belief and action" (p.1).

However, that process is not a static one. Critical thinking involves the constant analysis, evaluation and reevaluation of the information that is received or produced. For Scriven and Paul (2007) a critical thinker is always improving the quality of his or her thinking. 
This process requires a disciplined analysis and assessment of what is thought and said.

Elder \& Paul (2010) propose six stages any person should pass through to become a critical thinker. These stages start with what they have called the unreflective thinker stage, moving through other four stages: the challenged thinker, the beginning thinker, the practicing thinker, the advanced thinker, and finally reaching the master thinker stage. Becoming a critical thinker goes beyond the simple purpose of thinking different. For these authors, changing the way of thinking and acting is a long-range project.

Facione (1990), using the two-sentence definition of critical thinking generated from the Delphi Report, identified critical thinking as ' the process of purposeful, self-regulatory judgment. This process gives reasoned consideration to evidence, context, conceptualizations, methods, and criteria" (p. 5). This author also suggests that critical thinking involve both skill and habits of mind and dispositions.

Considering the previous definitions, but particularly Facione's one, we as researchers concluded that critical thinking is the constant and never-ending interactive process of observing, analyzing, reflecting and evaluating a reality; and this process can take place only when students are asked to address a situation and come up with a solution. This means that critical thinking is not a process enclosed inside the brain, but rather the development of critical thinking skills that human beings can develop with others.

\section{Critical Thinking Skills}

Regarding that the purpose of this study was to provide spaces for students to enhance their critical thinking skills, here it is relevant to define the concept of critical thinking skills.

Although Bloom's taxonomy is not the only framework of critical thinking, it is the most widely known and used by scholars. Bloom (1956) presents a taxonomy that divides the way people learn into three domains: cognitive, affective and psychomotor. The study here presented focused mainly on the cognitive domain which emphasizes intellectual outcomes. This domain is further divided into six categories: knowledge, comprehension, application, analysis, synthesis and evaluation. 
Anderson \& Krathwolh (2001) proposed a revision of Bloom's taxonomy where they re-named the categories aforementioned and provided some verbs to describe the actions a critical thinker displays. The following figure exemplifies this process of re-naming Bloom's taxonomy:

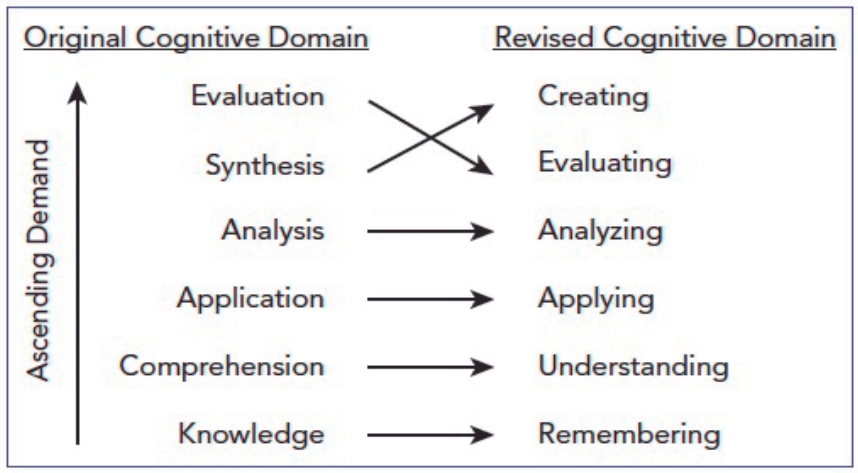

Figure 1. Revising Bloom's Taxonomy

Taken from: https://sharemylesson.com/blog/what-no-one-tellsyou-about-blooms-taxonomy

These new categories involve some cognitive skills that individuals should practice or master to become critical thinkers. As each category implies different cognitive skills, it is necessary to clarify that the actions proposed by Anderson \& Krathwolh (2001), in each of those categories, were at the center of the critical thinking skills we wanted to enhance in our students. In the following table there is presented the structure of the cognitive processes proposed by Krathwolh (2002) for the Cognitive Dimension. 
Table 1. Cognitive Processes of the Cognitive Process Dimension

\begin{tabular}{|c|}
\hline $\begin{array}{l}\text { Structure of the Cognitive Process } \\
\text { Dimension of the Revised Taxonomy }\end{array}$ \\
\hline $\begin{array}{l}\text { 1.0 Remember- Retrieving relevant Knoledge fromlong-termmemory } \\
1.1 \text { Recogiizing } \\
1.2 \text { Recalling }\end{array}$ \\
\hline $\begin{array}{l}\text { 2.0 Understand-Determining the meaning of instructional messages, including oral, } \\
\text { written and graphic communication. } \\
2.1 \text { Interpreting } \\
2.2 \text { Exenplifying } \\
2.3 \text { Classifying } \\
2.4 \text { Sunnuarizing } \\
2.5 \text { Inferring } \\
2.6 \text { Comparing } \\
2.7 \text { Explaining }\end{array}$ \\
\hline $\begin{array}{l}\text { 3.0 Apply-Carrying out or using a procedure in a given situation. } \\
\text { 3.1 Executing } \\
\text { 3.2 Inplementing }\end{array}$ \\
\hline $\begin{array}{l}\text { 4.0 Analyze-Breaking material into its constituent parts and detecting how the pasits } \\
\text { relate to one another and to an overall structure or purpose } \\
4.1 \text { Differentiating } \\
4.2 \text { Organizing } \\
4.3 \text { Attributing }\end{array}$ \\
\hline $\begin{array}{l}\text { 5.0 Evaluate-Making judgments based on criteria and standards. } \\
5.1 \text { Checking } \\
5.2 \text { Critiquing }\end{array}$ \\
\hline $\begin{array}{l}\text { 6.0 Create-Putting elements together to form a novel, coherent whole or make an } \\
\text { original product } \\
6.1 \text { Generating } \\
6.2 \text { Planning } \\
6.3 \text { Producing }\end{array}$ \\
\hline
\end{tabular}

Adapted from Krathwohl, 2002, p. 215

Regarding the information presented previously about critical thinking and about critical thinking skills, the following criteria were considered and applied along the different workshops to enhance our participants' critical thinking skills: 
1. These critical thinking skills should be constructed socially, that is to say by means of cooperative work.

2. They require a personal effort and commitment to have a progressive process.

3. We should start from the particular to the general; it means learners have to analyze their immediate reality first, and in that way, to have better understanding of the global phenomena.

4. It is necessary that learners make a constant assessment of their process, in order for them to be aware of their difficulties and strengths.

Finally, we consider that based on the previous criteria, learners should have the ability to act more critically towards the improvement of the world's reality.

\section{Cartoons}

Cartoons portray different events that occur in societies. The objective is focused on criticizing in a satirical and humoristic way particular issues and features that affect reality. For Monzon (2005) cartoons are an art in which life, customs and thought of a time or a town are expressed. Its highest value lies in discovering hidden but decisive qualities of a person or situation, provoking a smile or a frank laugh, as well as creating reflection and reaction analysis.

The Encyclopaedia Britannica (Macro-Paedia, vol.3) cited in Onakpa (2014, p. 34) states that "Cartoons sharpen the public's view of a contemporary or topical issue, event, political or social trend." It means that tendencies in the current world could be analyzed and criticized by the common population, and in some cases, change their perception of a particular reality, since, they are presented in an attractive and accessible way for people.

Besides, cartoons have two different purposes: to amuse and to inform people. During this research, cartoons were used combining its two purposes: to amuse since it uses sarcasm, exaggerated drawings; and to inform due to the social content they include. Cartoons can also be classified into animated cartoons and editorial cartoons where political cartoons are situated. 


\section{Political Cartoons.}

Political cartoons are a type of cartoons that is focused only on social or political events. They involve an image that shows exaggerated details of a politician, social problematic or famous event in order to picture a situation in a particular and very unique way. The idea of a political cartoon is to know the reality of a political system in an accessible and easier way, since it is shown through humoristic and funny graphics that catch people's attention to be active participants of society.

Political cartoons can be used as a pedagogical tool to promote critical thinking since they can be considered as a way to get information in a simple and entertained way. Walker (2003) claims that "one of the most powerful weapons that a cartoon has is its seemingly humor whose message can be absorbed easily, without much reflection or resistance" (p.16). However, as our population was teenagers, we wanted to approach political cartoons with the intention of moving them into a deeper analysis of this new type of text. We consider political cartoons as a new text; since this was the first time they were introduced and studied in this particular class.

Political cartoons also have the ability to summarize throughout pictures extended information that could be found in newspapers, critical articles and news in general. They generally are thought-provoking and attempt to educate the viewer about a current issue. They also have the purpose of dissecting and criticizing deeply a social and political issue, catching the audience's attention instantaneously (Wintz, Karaca, and Lang, 2003). It could be said that political cartoons were a different type of texts the participants had to read about the reality that surrounded them.

In the study here presented political cartoons were used as the main strategy to introduce the participants in the analysis of different political and social issues regarding the Colombian and the international context. Political cartoons were the excuse to go beyond those problems, to analyze them and to state a critical position about them.

\section{Instructional Design}

Throughout the first semester of 2017 year, five task-based workshops were developed with the pre-intermediate class. These workshops lasted two hours each one; meetings were scheduled every fifteen days during their English Classes. 
In order to enhance critical thinking skills in this group of students, we selected five contemporary topics that were related to their context and world's reality. Table 2 presents the topics and workshops developed based on those topics.

Table 2. Topics and workshops

\begin{tabular}{|l|l|}
\hline Topic & Workshop \\
\hline 1. Immigration & No Human Being is Illegal \\
\hline 2. Gender Inequality & Men-Women=equals \\
\hline 3. Social Networks & A Social Life \\
\hline 4. Corruption & Corrupted Minds \\
\hline 5. Global Warming & No Planet, No Life \\
\hline
\end{tabular}

After selecting the topics for the five workshops, we began a search for the political cartoons in the newspapers, internet and social media to work each topic. The topics presented in the next table approached a social or political issue we wanted to address in our classes; however we decided to state a title for each workshop that could be more attractive and meaningful to our participants. We presented this title as a warming up to introduce the issues to be approached in each workshop.

The workshops were designed around the Task- based approach proposed by Willis (1998). This author suggests that tasks are activities used to achieve a communicative objective, by using the target language. Throughout these tasks, our intention was also to promote and foster students' critical thinking skills. The tasks allowed students to analyze the political cartoon, reflect and interact with their partners to share their ideas, opinions and concerns in relation to the problematic issues there presented or portrayed.

This approach is developed by implementing six different types of task. These types include: listing, ordering and sorting, comparing, problem solving, sharing of personal experiences and creative tasks (Willis, 1998). Based on the tasks mentioned previously, five workshops were designed. These workshops included creative, diverse, fun and enjoyable content to promote critical participation in students. The structured model of task-based learning proposed by Willis and Willis (2007) was considered to organize the stages of each workshop. This model includes: Pre-task, Task preparation and Post task. 
Here it is presented briefly what each stage of the different taskbased workshops entailed:

Pre-task: During this stage, an introduction was made to get students' attention and prepared them for the topic that was going to be presented further on. This introduction was developed by using different videos, games and songs.

During this stage the political cartoons for each workshop were presented and shared with the students. Students had the chance to observe each political cartoon and comment around the topics there portrayed.

Task Preparation: In this stage, students were able to elaborate the central task, where they could analyze, explore their imagination, creativity, and share ideas among them. Students were involved in developing scale models, performances, posters and videos creation. Along the workshops, diverse activities for this stage were proposed to avoid repetitive activities.

Post task: This was the last stage of the workshops. Based on the activities the students developed during the task preparation stage, learners develop performances, exposition of the posters, and explanation of their own political cartoons and scale models. This was considered as the stage where the researchers could identify the critical thinking skills fostered or developed in each workshop.

\section{Type of Research}

This study followed the action research method which according to Koshy (2005) and Varcalcel (2009), consists of teachers studying class situations to improve their pedagogical practice. Four steps were taken into consideration as the action research principles state: observing, planning, acting and evaluating.

In the first step (observing) the lack of spaces to develop critical thinking in the language classes in the modern language program was identified; for that reason, the researchers agreed to foster this skill by implementing political cartoons as a pedagogical innovation for this class.

During the second step (planning) a structural plan conformed by five (5) workshops was created, it included pre-task, task, and posttask phases, implementing the task based model proposed by Willis and Willis (2007), in which students accomplish a communicative goal by means of small tasks and using the target language. 
In the third step, (acting) the workshops were implemented. During a series of two-hour sessions students developed the proposed activities in the workshops.

During the last step (evaluating) the researchers condensed the information gathered in the workshops and analyzed it in order to support the theory.

\section{Setting and participants}

The study was conducted at a public university in Colombia during the first academic semester in 2017. This university has two English teaching preparation programs: The Foreign Languages Bachelor Program and The Modern Languages Bachelor Program. The class selected for this study was a pre-intermediate level course according to the Common European Framework. They were in the $3^{\text {rd }}$ semester of their major and at this level they were expected to continue developing their communicative competence as well as to enhance their critical thinking skills. The students' ages ranged between 18 and 21 . This group studies an average of five (5) hours of English per week. For the study 10 out of 16 students accepted to participate voluntarily in the study and that was the data we analyzed. In this paper the names of the participants were replaced by $\mathrm{S}$ and a number.

\section{Data Collection}

Three collection methods were used: class video-recording, students' artifacts and a focus group. These instruments allowed the researchers to analyze and triangulate the data needed to answer the research question.

\section{Class video-recording}

Edwards and Westgate (1987) consider class video-recording allows a retrospective analysis of data. Students were recorded to analyze their behavior, interaction, and responses to the activities to determine the impact and effectiveness of them. It also let researchers to analyze the critical thinking skills that were enhanced in each workshop. 


\section{Students' artifacts}

They are "the range of written and symbolic records kept by or on participants in a social group" (Goetz and Lecompte, 1984, cited in Merriam, 1991, p.105).This instrument provided pertinent information about students' experiences and their process in the classroom to know their perception of different topics. In this sense, during the workshops students created a variety of artifacts like posters, reflective writings, performances, scale-models, and their own versions of political cartoons. The student's artifacts were mainly developed during the post - task stage. These artifacts were also analyzed to identify critical thinking skills.

\section{Focus Group}

Conducting focus groups is a qualitative research method that allowed researchers to collect a large amount of data from a substantial group of people in a relatively short amount of time (Bell, 2010). This focus group was conducted at the end of the study to go deeper in students' reflections, concerns and thoughts about the workshops and topics presented. Some unstructured questions were designed to allow students to express spontaneously about the social issues treated in class, the materials and how this had an impact in their immediate context. The group discussion was done with all the students of the class during one hour at the end of the study.

\section{Findings}

Grounded theory was applied to analyze the data. According to Strauss and Corbin (1990) grounded theory is a qualitative research method in which theory emerges from the students' data through the implementation of an inductive process rather than a deductive one. Taking into account the grounded theory method, we collected, transcribed, labeled, analyzed and interpreted data to answer the research question proposed for this study.

This process required a constant revision and reading of the information gathered from the sources that were applied with the intention of perceiving relevant aspects of the topic under study (Glaser and Strauss, 1967). In this case, this research aimed to analyze to what extent the implementation of political cartoons enhances critical thinking in pre-intermediate English level students. 
In order to integrate the collected information from the instruments, it was necessary to take into consideration the methodological triangulation proposed by Krathwohl (1993) which allowed us to use different sources to collect data and to confirm their reliability and veracity. The samples that support the data analysis are presented as students produced them, therefore grammar or spelling mistakes can be observed in those samples.

The findings were organized around two main categories: connecting the word with the world and identifying a path to follow. The names of these categories were established by the researchers during the labeling process. The data analysis here presented evidences that critical thinking skills cannot be separated and analyzed in isolation due to they are cognitive processes that cannot be separated, on the contrary these processes are overlapped and complemented.

\section{Connecting the Word with the World}

This category emerges from the analysis of the different instruments applied to collect data. While analyzing the data, it was possible to identify that the English language classroom was transformed into a space where the participants were learning not only about the language, but that language was transformed into a vehicle to learn, reflect, analyze and discuss about different current social and political issues. Here, there are presented some samples connected to this category:

'Your mental jail will protect you from reality' (S3, Workshop \#3 Social Life, poster about Social Networks, May 16)

"people now believe that social networks can help in real life, but that is incorrect because that is not a solution" (S6, Workshop \#3 A Social Life; video recording \#1, minute 2:50, May 16)

In terms of critical thinking skills and based on the previous samples we can say that these students were reflecting about what people consider as real life. It can be said that these students were identifying that sometimes people are not able to recognize the reality they are living in and, according to participants' analysis, it can happen because of the different media people are involved with every day.

This same situation was also observed by $\mathrm{S} 2$ :

"we can see some pictures or photos on social networks, and that give us an idea of a "perfect life" (Workshop \#3 A Social life; video recording \# 2, Minute: 1:5; May 16) 
In the same line of thought, the students S7, S8 and S9, complemented that idea with the following reflections:

the social networks create fake lives" (Workshop \#3, A Social life; poster about Social Networks; May 16)

"Social network is the modern slavery, because they (people) are always looking for new messages in WhatsApp or new posts on Facebook, or new stuff that doesn't have any meaning in the real life." (S5, Workshop \# 5, Focus Group, Minute: 20:05; June 1)

These participants are giving a description of what social networks mean to them and, in the case of S5, it is possible to evidence how he was able to state his own definition by comparing it with a modern slavery people accept, and he concluded stating that situation is not part of the real life. From these reflections we could see that participants perceive the social networks as spaces people use to escape from what they consider real life.

However, reflecting and comparing were not the only critical thinking skills that we could observe in the data analysis. We could perceive that while they were demonstrating understanding of information, facts and ideas by giving descriptions and stating main ideas, they were also presenting and defending opinions by making judgments about the same information, ideas or facts (Facione, 1990). The next samples evidence this analysis:

"You must recycle because the world needs you now" (S3, S6, S9, Workshop \#, 5 No Planet, No Life, class video-recording, Minute: 00:12; June 1). And, they concluded with the next idea: "the solution to clean and protect the world is in your hands. Recycle!" (Minute: 01:20).

In the previous sample, it is possible to see that these participants were connecting the situations happening outside the classroom and the possible solutions to the pollution issue. According to them, this problem can be solved if each person assumes that the world is in his/ her hands. In this sense, we could say that this group of students was not only identifying the problem, but they were also hypothesizing about a possible solution. They were aware of the problems that are in their immediate reality and they developed the necessity of attacking them by means of a systematically plan (Elder \& Paul, 2010).

This same situation was also evidenced in the next samples:

"We should change our society. A society blaming to the other is not the solution. The change is inside each one of us, being honest and 
good persons" (S3, Workshop \# 4, corrupted Minds, Reflective Writing activity; May 23, see annex 3)

Based on the previous analysis, it is possible to say that during the different workshops these students were enhancing different critical skills because they were not only reflecting about some social issues, but they also were demonstrating understanding of the facts presented in the political cartoons; they were also organizing their ideas to identify the causes of some current problems, but at the same time they were proposing solutions to those problems. All these cognitive processes are considered critical thinking skills (Krathwohl, 2002)

\section{Showing a path to follow}

The name of this category was identified in the different data collected. It was possible to see the impact that Political Cartoons cause on this group of students. Different participants were writing and discussing about the role of those cartoons in their life as students and also in the possibilities of using them in their future as language teachers. The next samples evidence this situation:

"cartoons are a creative way to keep our active role like citizens and think beyond our eyes" (S9, Workshop \# 4, corrupted Minds, Reflective Writing activity; May 23)

"the workshops helped us to realize the bad situations of the society and in our college, because sometimes we live outside of the reality, and we believe some problems don't affect us" (S3, Workshop \# 5, Focus group, class video-recording; Minute: 23:10; June 1st)

A similar statement was found in the same workshop. It was proposed by $\mathrm{S} 1$, but in this case, he mentioned specific issues that affect our society:

"Problems like corruption, powerful people can manipulate our society. Through political cartoons we can face those situations and analyze all the factors hidden on it" (Workshop \# 4, corrupted Minds, Reflective Writing activity; May 23)

On the other hand, some students proposed that society needs a deep change and it depends on people's acts to achieve it. It is the case of S7, when she said:

"All the scenarios that we have seen are the reflection of a society that has a lot of things to change. We need to know more about our context, about our problems and how those situations can change our 
life" (Workshop \# 4, corrupted Minds, Reflective Writing activity; May 23, see annex 3)

According to the students' samples, we can identify that they were able to recognize that even though many societies seem to be manipulated by corrupted governments, it is our responsibility as citizens to struggle with this, taking honesty, respect and tolerance as main principles. These previous samples also evidence the critical thinking skills students were enhancing. They are not only reflecting about an issue but they were also proposing alternatives to face those social and political issues.

These participants also expressed that this pedagogical implementation was meaningful for their professional lives as future teachers. It was possible to evidence that they were aware of their responsibility as future language teachers and their commitment on generating changes. The next samples evidence this observation:

"Like future teachers we should try to change the point of view of our students, invite to create a better world" (S7, Workshop \#4 Corrupted minds, Reflective Writing; May 23)

$\mathrm{S} 4$ fostered the previous reflection, by mentioning some aspects that highlight the responsibility and the important role that teachers play in societies.

"We as teachers should try to create awareness in our students because we are creating a new generation and we can influence in our students and give them new tools to change the situations" (S4, Focus Group, Minute: 15:16; June 1)

Likewise, S3, S6, S10, manifested what teachers have to do nowadays, especially in the Colombian context:

"Teachers have to construct something that is destroyed" (Workshop \# 4 Corrupted Minds, class video-recording, Minute: 01:48; May 23)

With this analysis, we can say that at this level, students were able to enhance some critical thinking skills and they had the possibility 158 to expand their critical vision about some social and political issues; although it was possible to see they were able to identify their roles as citizens and as future teachers, we consider there is still a life-long road they should follow to become skillful critical thinkers.

To sum up, it is important to highlight that students' critical thinking level had a progressive and meaningful improvement through 
the implementation of the five workshops carried out along the semester. They were able to go beyond analyzing local and global issues to look for solutions and new alternatives to overcome them. This progression can be related to the third and four stages proposed by Elder and Paul (2010) that individuals go through in order to become critical thinkers.

\section{Conclusions}

Taking into account that this study was designed to identify and analyze whether or not the implementation of some political cartoons enhanced or fostered pre-intermediate English students' critical thinking, and to determine how these could emerge with the implementation of some political cartoons, the participants were invited to actively participate in five workshops where they produced artifacts and participated in discussions related to diverse political issues.

Political cartoons was a different didactic alternative for this population since they were involved into the analysis of different political and social issues by using a different type of text that allowed them to connect the word with the world and therefore contributed into the enhancement of different critical thinking skills.

Based on the previous data analysis, it is possible to say that we could see our population was enhancing some critical thinking skills, since they were able to reflect, discuss, analyze and evaluate information presented in a political cartoon. They were also contrasting the issue presented in the cartoon with their own realities and they were proposing solutions to the problematic presented. However, we consider that it is necessary a constant practice to foster the development of these and other critical thinking skills.

Students argued that they achieved a critical opinion about the cartoons, because they could reflect about the topics that affect the society. They also highlighted that when they worked in groups they had the opportunity to listen to more points of view about the topics, so they had the possibility to reflect on them. They became more critical in regards to the society issues, because they realized those problems can affect them.

We, as language teacher-researchers consider necessary to continue creating spaces where students can learn not only the language but with the language. It is our responsibility to develop sharp, open and analytical minds to face the current globalized world. We should never forget that all education is political and that we teachers are called to empower kids to read the word and the world. 


\section{References}

Anderson, L. W., \& Krathwohl, D. R. (2001). A Taxonomy for Learning, Teaching, and Assessing: A revision of Bloom's Taxonomy of Educational Objectives. (Abridged edition, first edition) New York, N.Y.: Pearson.

Arango, J., Gomez, L., \& Gomez, M. (2009). El cómic es cosa seria. El cómic como mediación para la enseñanza en la educación superior. Anagramas, 7 (14), 13-32.

Arias, D. (2014). Critical thinking development by using implicit content of songs: an alternative to incorporate music in the classroom (Unpublished master's thesis). Universidad Pedagógica y Tecnológica de Colombia. Tunja.

Bell, J. (2010). Doing your research project: A guide for first-time researchers in education, health and social sciences. New York, NY: Open University.

Bloom, B. (1956). Taxonomy of Educational Objectives, Handbook I: The Cognitive Domain. New York: David McKay Co Inc.

Carvajal, N., Poveda, F., \& Rojas, A. (2012). Didactic Unit Designed Using Critical thinking: A way to improve your skills. Enletawa Journal, 5, 7-20.

Dougherty, B. (2002). Comic relief: Using political cartoons in the classroom. International Studies Perspectives, 3, 258-270.

Edwards, A; Westgate, D. (1987). Investigating Classroom Talk. Lewes: Falmer Press.

Elder, L., \& Paul, R. (2010). The thinker's guide to analytic thinking. Dillon Beach, CA: Foundation for Critical Thinking Press.

El Refaie, E \& Horschelmann, K. (2010). Young people's readings of a political cartoon and the concept of multimodal literacy. Discourse: Studies in the Cultural Politics of Education, 32 (2), 195,207. DOI: 10.1080/01596301003679719

Facione, A. (1990). Executive summary of critical thinking: A statement of expert consensus for purposes of educational assessment and instruction, Berkeley: The California Academic Press.

Freire, P. (2008). Education for critical consciousness. London: Continuum.

Glaser, B., \& Strauss, A. (1967). The discovery of grounded theory: Strategies for qualitative research. Chicago: Aldine Publishers. 
Ibarra, L., \& Ballester, J. (2015). Comics Interculturales, Educación Literaria y Productos Políticamente Correctos. Retrieved from https://digitum.um.es/xmlui/bitstream/10201/ 42932/1/Comics\%20 interculturales.pdf.

Koshy, V. (2005). 1 What is action research?. In Action Research for Improving Practice: A Practical Guide (pp18-40). Thousand Oaks, CA: SAGE Publications.

Krathwohl, D. (1993). Methods of Educational and Social Science Research: An Integrated Approach. New York: Longman.

Krathwohl, D. (2002). A Revision of Bloom's Taxonomy: An Overview. Theory into Practice, 41, 212-218. http://dx.doi.org/10.1207/ s15430421tip4104_2

Merriam, S. (1991). Case Study Research in Education: A qualitative Approach. San Francisco. Oxford: Jossey-Bass Publishers.

Monzon, C. (2005). La prensa y la caricatura como fuente de información en el proceso educativo. Revista de Teoría y Didáctica de las Ciencias Sociales, 10, 175-183. Retrieved from: http://www. redalyc.org/pdf/652/65201009.pdf

Onakpa, M. (2014). Cartoons, cartoonists and effective communication in the Nigeria Print Media. African Research Review, 8 (1), 32-41.

Scriven, M., \& Paul, R. (2007). Defining critical thinking. The Critical Thinking Community: Foundation for Critical Thinking. Retrieved from http://www.criticalthinking.org/ aboutCT/define critical thinking.cfm

Strauss, A. L., \& Corbin, J. M. (1990). Basics of qualitative research: Grounded theory procedures and techniques. Newbury Park, Calif: Sage Publications.

Valcarcel, D. (2009). Action research essentials. San Francisco: JosseyBass.

Walker, R. (2003). Political cartoons: now you see them. Canadian Parliamentary Review, 26 (1), 16-21.

Willis, D., \& Willis, J. (2007). Doing Task-Based Teaching. Oxford Handbooks for Language Teachers. Oxford: OUP(Oxford University Press).Willis, J. (1998). A framework for task-based learning. England: Longman. 
Wintz, T., Karaca, C., \& Lang, K. (2003). Understanding the world of Political Cartoons. The Seattle Times Company Newspapers in Education. Retrieved from https://www.world-affairs.org/wpcontent/uploads/2013/10/2003-Understanding-Political-Cartoons. pdf 


\section{Authors}

* María Teresa Esteban Núñez holds a BA in Modern Languages and an MA in Language Teaching from Universidad Pedagógica y Tecnológica de Colombia. She is a full time teacher-researcher in the undergraduate and postgraduate programs at the same University. She is a member of the research group Knowledge in Action (KIA).

Adriana Márquez Medina holds a BA in Foreign Languages from Universidad Pedagógica y Tecnológica de Colombia. She is a member of the research group Knowledge in Action (KIA) in the same University. She has worked also as project developer in rural and urban contexts. Currently, she is an English teacher in a private institution.

Jhon Everth Ortiz Cubides holds a BA in Foreign Languages from Universidad Pedagógica y Tecnológica de Colombia. He is a member of the research group Knowledge in Action (KIA) in the same University. He currently works as a teacher assisstant at Robbinsdale Spanish Immersion School in Minneapolis, MN in the USA. 